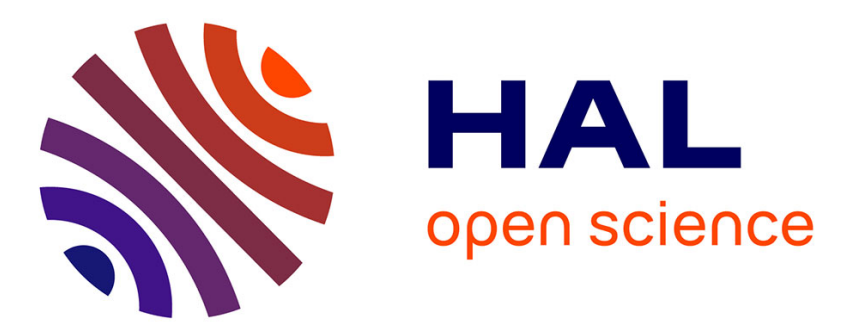

\title{
Erratum - The E2 6S-7S amplitude in Cesium and its importance in a precise calibration of EPV 1.
}

\author{
M.A. Bouchiat, J. Guena
}

\section{To cite this version:}

M.A. Bouchiat, J. Guena. Erratum - The E2 6S-7S amplitude in Cesium and its importance in a precise calibration of EPV 1.. Journal de Physique, 1989, 50 (7), pp.843-843. 10.1051/jphys:01989005007084300 . jpa-00210961

\section{HAL Id: jpa-00210961 https://hal.science/jpa-00210961}

Submitted on 1 Jan 1989

HAL is a multi-disciplinary open access archive for the deposit and dissemination of scientific research documents, whether they are published or not. The documents may come from teaching and research institutions in France or abroad, or from public or private research centers.
L'archive ouverte pluridisciplinaire HAL, est destinée au dépôt et à la diffusion de documents scientifiques de niveau recherche, publiés ou non, émanant des établissements d'enseignement et de recherche français ou étrangers, des laboratoires publics ou privés. 


\section{Erratum}

The $E_{2}$ 6S-7S amplitude in Cesium and its importance in a precise calibration of $E_{1}^{\mathrm{PV}}$.

M. A. Bouchiat and J. Guena

(J. Phys. France 49 (1988) 2037-2044)

Equation (4) is misprinted : the sign = in front of the third line has to be suppressed. 